The Spectrum of

Clean Energy Innovation

\title{
NREL Triples Previous Estimates of U.S. Wind Power Potential
}

The National Renewable Energy Laboratory (NREL) recently released new estimates of the U.S. potential for wind-generated electricity, using advanced wind mapping and validation techniques that triple previous estimates of the size of the nation's wind resources. The new study, conducted by NREL and AWS TruePower, finds that the contiguous 48 states have the potential to generate up to 37 million gigawatt-hours annually. In comparison, the total U.S. electricity generation from all sources was roughly 4 million gigawatt-hours in 2009.

Detailed state-by-state estimates of wind energy potential for the United States show the estimated average wind speeds at an 80-meter height. The wind resource maps and estimates provide local, state, and national policymakers with accurate information about the nature of the wind resource in their areas and across the nation, helping them to make informed decisions about wind energy.

In addition to policymakers, wind developers and energy providers require accurate estimates of how much wind energy is available at potential development sites. Correct estimates of the wind energy available can make or break the economics of wind plant development. Location of wind resources is a critical component for planners to expand wind capacity. In addition, energy providers need to know the "when" and "where" to supply transmission needs. The new maps provide updated data that can be used in models to determine the optimal location for wind plants and set the stage for cost-effective transmission infrastructure planning.

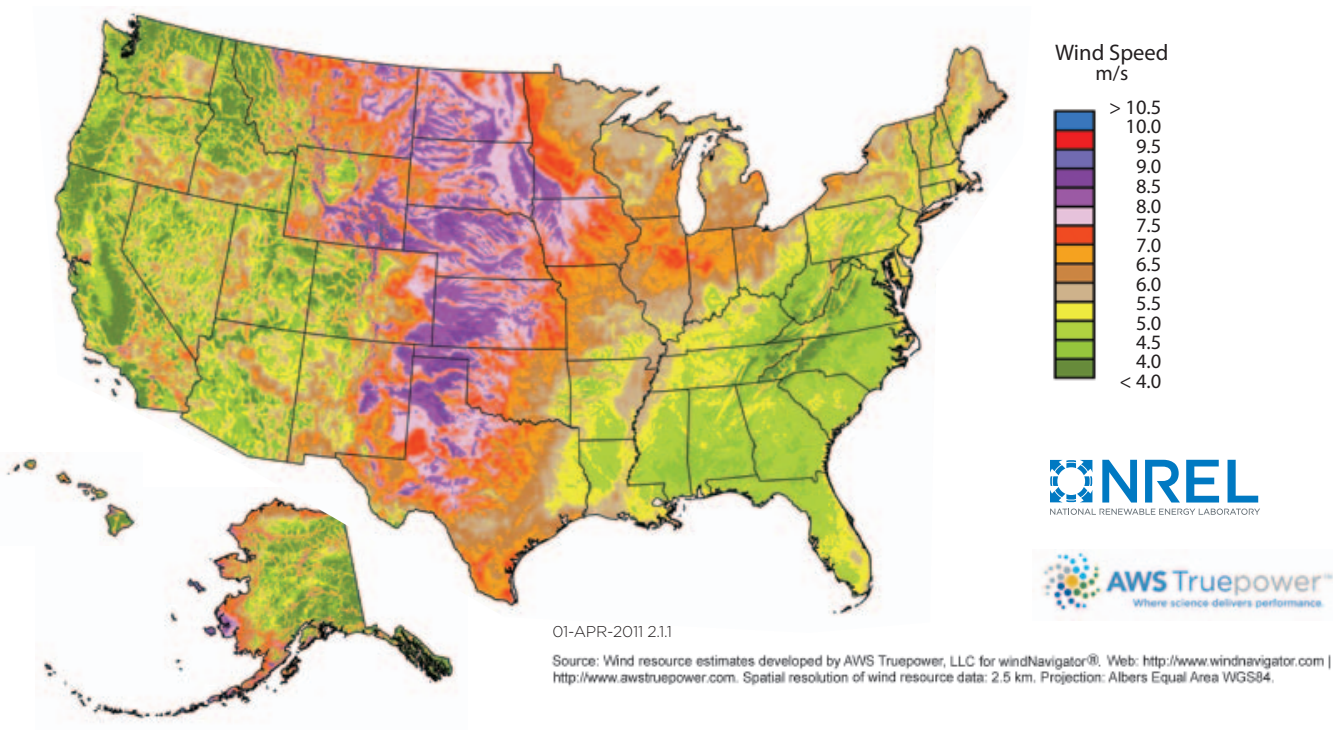

NREL's updated U.S. wind resource assessment finds significant new wind resources at 80 meters above the ground, as shown in this map.

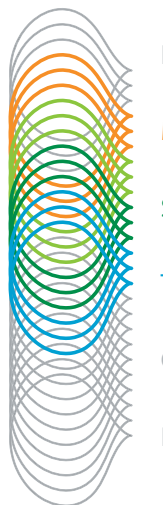

Fundamental Science

Market-Relevant Research

Systems Integration

Testing and Validation

Commercialization

Deployment

Through deep technical expertise and an unmatched breadth of capabilities, NREL leads an integrated approach across the spectrum of renewable energy innovation. From scientific discovery to accelerating market deployment, NREL works in partnership with private industry to drive the transformation of our nation's energy systems.

This case study illustrates NREL's analysis and decision-support capabilities, which enhance innovation across the spectrum. This example highlights analysis contributions in Market-Relevant Research through Testing and Validation.

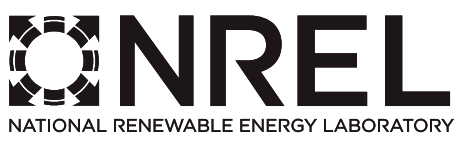

NREL is a national laboratory of the U.S. Department of Energy, Office of Energy Efficiency and Renewable Energy, operated by the Alliance for Sustainable Energy, LLC. 
The new estimates reflect substantial advances in wind resource assessment technology that have occurred since the last national wind resource assessment was conducted in 1993. Geographic Information System mapping tools; an array of data from satellites, weather balloons, and meteorological towers; and much-improved computer models provide higher spatial resolution than was available for previous estimates. The higher resolution allows for a more accurate depiction of the overall wind resource.

Previous wind resource maps showed the wind resource at 50 meters (about 164 feet) above the ground, which was the height of many wind turbine towers at the time. The new maps show average wind speeds at an 80-meter height (about 262 feet), the height of today's turbines. Because wind speed generally increases with height, turbines built on taller towers can capture more energy and generate more electricity. The new maps also provide data at 100 meters (about 328 feet).

NREL validated the new estimates with wind tower measurement data from more than 300 locations. When the new products were posted to the Wind Powering America website, the all-time records for numbers of visitors were broken. To see the detailed maps, visit www.windpoweringamerica.gov/wind_maps.asp.

Tables provided in the report list a maximum installed capacity for each state, assuming an installed capacity of 5 megawatts (MW) for each square kilometer of available windy land area at the 80-meter height. A square kilometer of land equals about 247 acres. The maps excluded areas unlikely to be developed, such as urban areas, wilderness areas, national parks, and water bodies, with a 3-kilometer buffer around urban and environmental lands.

Windy lands were defined as areas that, if developed with wind plants, would operate at more than a 30\% capacity factor, which means that on average, the plant will produce $30 \%$ of the power that it could produce if the wind constantly blew at the ideal speed for maximum power generation. For instance, a 100-MW wind plant operating at 30\% capacity factor would produce an average power output of $30 \mathrm{MW}$. Capacity factors of $30 \%$ or more are generally considered to be suitable for wind energy development.

Most of the U.S. wind potential comes from windy central regions, but many eastern and western states have significant wind potential. Thirty-five states have more than 1,000 MW of potential capacity at 80 meters and 38 states have more than 1,000 MW of potential capacity at 100 meters.

The report also includes calculations of the wind energy generation that could be produced from this hypothetical installed capacity. The annual generation in each state depends on the windy area and the estimated capacity factor of that windy area; the higher the capacity factor, the greater the electricity generation. For example, New Mexico has more windy area at 30\% and greater capacity factor than does Minnesota. However, Minnesota has more area with a 40\% capacity factor. As a result, it has the potential for more annual generation.

The study and maps have led to the identification of new wind development areas where the wind resource was previously considered unsuitable. They provide the wind industry, policymakers, and other stakeholders with wind resource data to effectively evaluate the wind resource and identify new opportunities for wind development.

\section{Which States have the Greatest Potential for Wind Power?}

NREL analyzed the new wind resource data to determine the maximum potential wind power capacity and wind generation, first by limiting the analysis to areas suitable for wind power development and then by finding those areas where an 80-meter-high wind turbine would operate, on average, at $30 \%$ of its maximum generation potential. Based on this analysis, the states with the greatest potential wind capacity are:
(1) Texas
(2) Kansas
(3) Montana
(4) Nebraska
(5) South Dakota
6 North Dakota
(7) lowa
8 Wyoming
9) Oklahoma
(10) New Mexico

The top 10 states with the most potential for wind power generation are:
(1) Texas
(2) Kansas
(3) Nebraska
(4) South Dakota
(5) Montana
6 North Dakota
(7) lowa
8 Wyoming
(9) Oklahoma
(10) Minnesota

\section{National Renewable Energy Laboratory}

1617 Cole Boulevard

Golden, Colorado 80401

303-275-3000 • www.nrel.gov

NREL is a national laboratory of the U.S. Department of Energy, Office of Energy Efficiency and Renewable Energy, operated by the Alliance for Sustainable Energy, LLC.

NREL/FS-6A42-51555 • July 2011

Printed with a renewable-source ink on paper containing at least $50 \%$ wastepaper, including $10 \%$ post consumer waste. 